\title{
Association of PRDM16 rs12409277 and CtBP2 rs1561589 gene polymorphisms with lipid profile of adolescents
}

Nela Maksimovic ${ }^{1}$, Vanja Vidovic ${ }^{2}$, Tatjana Damnjanovic ${ }^{1}$, Biljana Jekic ${ }^{1}$, Nada Majkic Singh ${ }^{3}$, Slavko Simeunovic ${ }^{4}$, Dara Savic Bozovic ${ }^{5}$, Stojko Vidovic², Ivana Novakovic ${ }^{1}$

\author{
${ }^{1}$ Institute of Human Genetics, Faculty of Medicine, University of Belgrade, Serbia \\ ${ }^{2}$ Faculty of Medicine, University of Banja Luka, Banja Luka, Bosnia and Herzegovina \\ ${ }^{3}$ Society of Medical Biochemists, Belgrade, Serbia \\ ${ }^{4}$ University Children's Hospital, Belgrade, Serbia \\ ${ }^{5}$ Uzice General Hospital, Uzice, Serbia
}

Submitted: 25 April 2019

Accepted: 18 October 2019

Arch Med Sci

DOI: https://doi.org/10.5114/aoms/113174

Copyright (c) 2020 Termedia \& Banach

\begin{abstract}
Introduction: Positive regulatory domain containing 16 (PRDM16) protein represents the key regulator of brown adipose tissue (BAT) development. It induces brown fat phenotype and represses white adipose tissue specific genes through the association with $C$-terminal binding co-repressor proteins (CtBP1 and CtBP2). In healthy adults presence of BAT has been associated with lower glucose, total cholesterol and LDL (low-density lipoprotein) cholesterol levels. Our aim was to analyze the association of PRDM16 gene (rs12409277) and CtBP2 gene (rs1561589) polymorphisms with body mass index (BMI), fasting glucose level and lipid profile of adolescents.

Material and methods: Our study included 295 healthy school children, 145 boys (49.2\%) and 150 girls (50.8\%), 15 years of age. Genotypes for the selected polymorphisms were detected by the real-time PCR method. Age, gender, height, weight, lipid profile (total cholesterol, HDL cholesterol, LDL cholesterol, triglycerides) and fasting glucose levels were recorded.

Results: We did not find a statistically significant association of rs 12409277 and rs1561589 polymorphisms with BMI, fasting glucose and lipid profile of adolescents. We further analyzed the combined effect of the two SNPs and the statistical analysis showed that carriers of CT genotype of rs 12409277 polymorphism and GG genotype of rs1561589 polymorphism had significantly lower total cholesterol $(p=0.001)$ and LDL cholesterol $(p=0.008)$ levels compared to all other groups of genotypes.

Conclusions: Our study suggests that rs 12409277 and rs 1561589 polymorphism might have an influence on total and LDL cholesterol levels in adolescents. Larger studies should be performed in order to confirm our results.
\end{abstract}

Key words: polymorphisms, BMI, lipids, adolescents, brown adipose tissue.

\section{Introduction}

During childhood, brown adipose tissue (BAT) dissipates chemical energy to produce heat as a defense against hypothermia and obesity and has an important role in weight determination and musculoskeletal development $[1,2]$. Activity of BAT may vary depending on age, gender, adiposity and temperature [3]. It has been shown that volume and activity of BAT especially increases during puberty [4], probably because of the effect of sex

\author{
Corresponding author: \\ Nela Maksimovic \\ Institute of Human Genetics \\ Faculty of Medicine \\ University of Belgrade \\ 26 Visegradska St \\ 11000 Belgrade, Serbia \\ Phone: +381113607040 \\ E-mail: \\ nela.maksimovic@med.bg.ac.rs
}


steroids and growth hormone [5, 6]. Discovery of presence of BAT in adolescents and adults raised many questions about its physiology, function, possible influence on human health and possible treatment options. The activity of BAT in adults has been associated with body mass index (BMI), body fat mass and glucose metabolism [7]. It has been observed that healthy adults with BAT have lower glucose, total cholesterol (TC) and low-density lipoprotein cholesterol (LDL-C) levels compared to individuals without BAT $[7,8]$. Brown adipose tissue volume was significantly associated with increased whole-body lipolysis, triglyceride fatty acid cycling, triglyceride-free fatty acid (FFA) oxidation and adipose tissue insulin sensitivity [9].

Positive regulatory domain containing 16 (PRDM16) protein, a $140 \mathrm{kDa}$ zinc-finger protein, is a key regulator of BAT development. Its expression is highly elevated in BAT, where it induces brown fat phenotype as a co-activator of PGC1 $\alpha$, PPAR $\alpha$, PPAR $\gamma, C / E B P$ and thyroid receptor [10]. PRDM16 also acts as a repressor of white fat cells expressed genes through association with $C$-terminal binding co-repressor proteins (CtBP1 and CtBP2) [11].

In the $5^{\prime}$-flanking region the PRDM 16 gene contains the polymorphism rs12409277. It has been suggested that $\mathrm{T}$ to $\mathrm{C}$ change in this polymorphism might influence the transcriptional activity of the gene [12].

CtBP2 controls cellular processes by acting as a transcriptional corepressor, transcriptional activator and regulator of the cytoskeleton [13]. An intronic polymorphism within the CtBP2 gene, rs1561589, has been previously associated with BMI in females [14].

The aim of our research was to investigate the association of rs12409277 polymorphism within the PRDM16 gene and rs1561589 polymorphism within the CtBP2 gene with BMI, fasting glucose level and lipid profile of adolescents.

\section{Material and methods}

\section{Study design and study population}

Our study included 295 randomly selected healthy school children of both genders, 15 years of age, who participated in Yugoslav Study of the Precursors of Atherosclerosis in School Children (YUSAD). Anthropometric, demographic and medical data including age, gender, height, weight, lipid profile (TC, high-density lipoprotein cholesterol (HDL-C), LDL-C, triglycerides (TG)) and fasting glucose were recorded. Children were classified as normal weight, overweight (above $85^{\text {th }}$ percentile) and obese (above $97^{\text {th }}$ percentile) according to BMI charts published for Serbian children 15 years of age [15]. Criteria for exclusion from the study were type 1 or type 2 diabetes, generalized inflammation, cardiovascular diseases, malignant diseases, genetic syndromes and chronic immobility or cerebral palsy. A signed informed consent form was obtained from each child's parent or guardian and the study protocol was approved by the Ethics Committee of Faculty of Medicine, University of Belgrade, Serbia.

\section{Genotyping}

Molecular-genetic analyses were performed at the Institute of Human Genetics, Faculty of Medicine, University of Belgrade, Serbia. DNA was extracted from $5 \mathrm{ml}$ of peripheral blood by the salting out method [16]. Genotypes of the selected polymorphisms were detected by the real-time PCR method using pre-designed TaqMan SNP Genotyping assays. PCR amplification included an initial step at $95^{\circ} \mathrm{C}$ for 10 minutes and 40 cycles of 15 seconds at $92^{\circ} \mathrm{C}$ and 1 minute at $60^{\circ} \mathrm{C}$. PCR and post-PCR fluorescence analyses were performed on the Applied Biosystems 7500 Real Time PCR System (Applied Biosystems, Foster (ity, CA), and the results were analyzed using the Applied Biosystems 7500 software v2.0.6 (Applied Biosystems, Foster City, CA).

Table I. Main characteristics of adolescents included in the study

\begin{tabular}{|lcccc|}
\hline Parameter & All & Boys & Girls & $P$-value \\
\hline BMI $\left[\mathrm{kg} / \mathrm{m}^{2}\right]$ & $22.08 \pm 4.31$ & $21.86 \pm 4.33$ & $22.26 \pm 0.63$ & 0.244 \\
\hline SBP $[\mathrm{mm} \mathrm{Hg}]$ & $114.77 \pm 12.53$ & $116.64 \pm 14.22$ & $112.96 \pm 10.37$ & $0.012^{*}$ \\
\hline DBP $[\mathrm{mm} \mathrm{Hg}]$ & $72.91 \pm 9.12$ & $73.09 \pm 9.63$ & $72.74 \pm 8.62$ & 0.745 \\
\hline FPG $[\mathrm{mmol} / \mathrm{l}]$ & $4.72 \pm 0.58$ & $4.79 \pm 0.53$ & $4.64 \pm 0.63$ & $0.005^{*}$ \\
\hline Tg $[\mathrm{mmol} / \mathrm{l}]$ & $0.99 \pm 0.55$ & $0.99 \pm 0.63$ & $1.00 \pm 0.47$ & 0.213 \\
\hline TC $[\mathrm{mmol} / \mathrm{l}]$ & $4.36 \pm 0.87$ & $4.21 \pm 0.79$ & $4.50 \pm 0.92$ & $0.003^{*}$ \\
\hline HDL-C $[\mathrm{mmol} / \mathrm{l}]$ & $1.42 \pm 0.41$ & $1.38 \pm 0.43$ & $1.45 \pm 0.39$ & 0.164 \\
\hline LDL-C $[\mathrm{mmol} / \mathrm{l}]$ & $2.48 \pm 0.87$ & $2.40 \pm 0.84$ & $2.55 \pm 0.90$ & 0.122 \\
\hline
\end{tabular}

$B M I$ - body mass index, SBP - systolic blood pressure, DBP - diastolic blood pressure, FPG - fasting plasma glucose, Tg - triglycerides, $T C$ - total cholesterol, HDL-C - high-density lipoprotein cholesterol, LDL-C - low-density lipoprotein cholesterol. " $P$-value $<0.05$. 


\section{Biochemical analysis}

Each individual fasted for $12 \mathrm{~h}$ before sample collection. Serum glucose, total cholesterol, HDL-C and triglyceride levels were measured as described previously [17]. LDL-C concentrations in samples were calculated using Friedewald's equation (LDL-C = TC $-\mathrm{HDL}-\mathrm{C}-\mathrm{TG} / 5)$ [18].

\section{Statistical methods}

For statistical analyses, the statistical software package SPSS 17 was used. Quantitative variables were expressed as mean \pm standard deviation. The association of genotypes and BMI, fasting glucose level and serum lipid levels was tested by analysis of variance (ANOVA) or the KruskalWallis test. After the grouping of genotypes Student's $t$-test or the Mann-Whitney test was used, depending on the variable distribution. In order to evaluate the association of serum lipid levels and PRDM 16 and CtBP2 genotypes with gender, fasting glucose level and BMI as covariates, multivariate linear regression analysis was also performed.

\section{Results}

Our study included 295 school children 15 years of age. There were 145 boys (49.2\%) and 150 girls
(50.8\%). Among boys, 26 (17.9\%) were overweight and $20(13.8 \%)$ were obese. In the group of girls, $29(19.3 \%)$ were overweight and 17 were obese (11.3\%). The main characteristics of adolescents are presented in Table I. There was a statistically significant difference in mean values of systolic blood pressure, fasting glucose level and TC level between the groups of boys and girls.

Frequencies of genotypes and alleles of rs12409277andrs1561589polymorphismsarepresented in Table II. The distributions of genotypes

Table II. Frequencies of rs12409277 and rs1561589 genotypes and alleles, $n(\%)$

\begin{tabular}{|cccc|}
\hline Genotypes & Frequency, $n$ (\%) & Alleles & Frequency \\
\hline rs12409277 & & & \\
\hline TT & $242(82.03)$ & & 0.91 \\
\hline CT & $52(17.63)$ & & C \\
\hline CC & $1(0.34)$ & & 0.09 \\
\hline rs1561589 & & & \\
\hline GG & $128(43.39)$ & G & 0.65 \\
\hline GA & $129(43.73)$ & A & 0.35 \\
\hline AA & $38(12.88)$ & & \\
\hline
\end{tabular}

Table III. Mean values of analyzed parameters by PRDM16 rs12409277 genotype (mean \pm SD)

\begin{tabular}{|c|c|c|c|c|c|c|}
\hline Parameter/Genotype & All & $P$-value & Boys & $P$-value & Girls & $P$-value \\
\hline \multicolumn{7}{|l|}{$\mathrm{BMI}\left[\mathrm{kg} / \mathrm{m}^{2}\right]$} \\
\hline TT & $21.99 \pm 4.30$ & \multirow[t]{2}{*}{0.327} & $21.74 \pm 4.22$ & \multirow[t]{2}{*}{0.474} & $22.21 \pm 4.39$ & \multirow[t]{2}{*}{0.434} \\
\hline $\mathrm{CT}+\mathrm{CC}$ & $22.54 \pm 4.38$ & & $22.47 \pm 4.92$ & & $22.45 \pm 3.96$ & \\
\hline \multicolumn{7}{|l|}{$\mathrm{FPG}[\mathrm{mmol} / \mathrm{l}]$} \\
\hline $\mathrm{TT}$ & $4.72 \pm 0.60$ & \multirow[t]{2}{*}{0.790} & $4.79 \pm 0.52$ & \multirow[t]{2}{*}{0.919} & $4.65 \pm 0.67$ & \multirow[t]{2}{*}{0.793} \\
\hline $\mathrm{CT}+\mathrm{CC}$ & $4.70 \pm 0.48$ & & $4.79 \pm 0.52$ & & $4.59 \pm 0.40$ & \\
\hline \multicolumn{7}{|l|}{$\operatorname{Tg}[\mathrm{mmol} / \mathrm{l}]$} \\
\hline $\mathrm{TT}$ & $1.00 \pm 0.58$ & \multirow[t]{2}{*}{0.442} & $0.99 \pm 0.66$ & \multirow[t]{2}{*}{0.555} & $1.02 \pm 0.49$ & \multirow[t]{2}{*}{0.229} \\
\hline $\mathrm{CT}+\mathrm{CC}$ & $0.92 \pm 0.38$ & & $0.99 \pm 0.46$ & & $0.90 \pm 0.38$ & \\
\hline \multicolumn{7}{|l|}{$\mathrm{TC}[\mathrm{mmol} / \mathrm{l}]$} \\
\hline TT & $4.40 \pm 0.87$ & \multirow[t]{2}{*}{0.067} & $4.21 \pm 0.79$ & \multirow[t]{2}{*}{0.739} & $4.57 \pm 0.92$ & \multirow[t]{2}{*}{$0.037^{*}$} \\
\hline $\mathrm{CT}+\mathrm{CC}$ & $4.20 \pm 0.84$ & & $4.17 \pm 0.81$ & & $4.21 \pm 0.86$ & \\
\hline \multicolumn{7}{|l|}{$\mathrm{HDL}-\mathrm{C}[\mathrm{mmol} / \mathrm{l}]$} \\
\hline $\mathrm{TT}$ & $1.42 \pm 0.42$ & \multirow[t]{2}{*}{0.930} & $1.40 \pm 0.44$ & \multirow[t]{2}{*}{0.328} & $1.43 \pm 0.39$ & \multirow[t]{2}{*}{0.340} \\
\hline $\mathrm{CT}+\mathrm{CC}$ & $1.41 \pm 0.36$ & & $1.30 \pm 0.36$ & & $1.51 \pm 0.34$ & \\
\hline \multicolumn{7}{|l|}{ LDL-C [mmol/l] } \\
\hline TT & $2.51 \pm 0.88$ & \multirow[t]{2}{*}{0.170} & $2.39 \pm 0.85$ & \multirow[t]{2}{*}{0.828} & $2.61 \pm 0.90$ & \multirow[t]{2}{*}{0.054} \\
\hline $\mathrm{CT}+\mathrm{CC}$ & $2.36 \pm 0.82$ & & $2.41 \pm 0.80$ & & $2.29 \pm 0.85$ & \\
\hline
\end{tabular}

${ }^{\star} P$-value $<0.05$ 
Nela Maksimovic, Vanja Vidovic, Tatjana Damnjanovic, Biljana Jekic, Nada Majkic Singh, Slavko Simeunovic, Dara Savic Bozovic, Stojko Vidovic, Ivana Novakovic

Table IV. Mean values of analyzed parameters by CtBP2 rs1561589 genotype (mean \pm SD)

\begin{tabular}{|c|c|c|c|c|c|c|}
\hline Parameter/Genotype & All & $P$-value & Boys & $P$-value & Girls & $P$-value \\
\hline \multicolumn{7}{|l|}{$\mathrm{BMI}\left[\mathrm{kg} / \mathrm{m}^{2}\right]$} \\
\hline GG & $21.90 \pm 3.89$ & \multirow[t]{3}{*}{0.897} & $21.58 \pm 3.78$ & \multirow[t]{3}{*}{0.928} & $22.19 \pm 4.00$ & \multirow[t]{3}{*}{0.516} \\
\hline GA & $22.15 \pm 4.79$ & & $22.13 \pm 4.86$ & & $22.18 \pm 4.74$ & \\
\hline AA & $22.26 \pm 4.20$ & & $21.38 \pm 4.10$ & & $23.22 \pm 4.20$ & \\
\hline \multicolumn{7}{|l|}{$\mathrm{FPG}[\mathrm{mmol} / \mathrm{l}]$} \\
\hline GG & $4.69 \pm 0.57$ & \multirow[t]{3}{*}{0.259} & $4.80 \pm 0.55$ & \multirow[t]{3}{*}{0.153} & $4.59 \pm 0.57$ & \multirow[t]{3}{*}{0.578} \\
\hline GA & $4.76 \pm 0.61$ & & $4.80 \pm 0.52$ & & $4.71 \pm 0.70$ & \\
\hline AA & $4.58 \pm 0.77$ & & $4.52 \pm 0.93$ & & $4.64 \pm 0.56$ & \\
\hline \multicolumn{7}{|l|}{$\mathrm{Tg}[\mathrm{mmol} / \mathrm{l}]$} \\
\hline GG & $0.93 \pm 0.39$ & \multirow[t]{3}{*}{0.397} & $0.88 \pm 0.37$ & \multirow[t]{3}{*}{0.564} & $0.97 \pm 0.40$ & \multirow[t]{3}{*}{0.703} \\
\hline GA & $1.06 \pm 0.66$ & & $1.10 \pm 0.84$ & & $1.01 \pm 0.40$ & \\
\hline AA & $1.01 \pm 0.62$ & & $0.93 \pm 0.33$ & & $1.10 \pm 0.82$ & \\
\hline \multicolumn{7}{|l|}{$\mathrm{TC}[\mathrm{mmol} / \mathrm{l}]$} \\
\hline GG & $4.32 \pm 0.91$ & \multirow[t]{3}{*}{0.164} & $4.17 \pm 0.77$ & \multirow[t]{3}{*}{0.625} & $4.47 \pm 1.00$ & \multirow[t]{3}{*}{0.191} \\
\hline GA & $4.45 \pm 0.86$ & & $4.28 \pm 0.84$ & & $4.64 \pm 0.85$ & \\
\hline AA & $4.17 \pm 0.78$ & & $4.13 \pm 0.62$ & & $4.21 \pm 0.93$ & \\
\hline \multicolumn{7}{|l|}{$\mathrm{HDL}-\mathrm{C}[\mathrm{mmol} / \mathrm{l}]$} \\
\hline GG & $1.42 \pm 0.36$ & \multirow[t]{3}{*}{0.743} & $1.38 \pm 0.35$ & \multirow[t]{3}{*}{0.993} & $1.46 \pm 0.37$ & \multirow[t]{3}{*}{0.511} \\
\hline GA & $1.41 \pm 0.46$ & & $1.37 \pm 0.51$ & & $1.45 \pm 0.40$ & \\
\hline AA & $1.37 \pm 0.35$ & & $1.38 \pm 0.36$ & & $1.35 \pm 0.34$ & \\
\hline \multicolumn{7}{|l|}{ LDL-C [mmol/l] } \\
\hline GG & $2.46 \pm 0.82$ & \multirow[t]{3}{*}{0.293} & $2.39 \pm 0.71$ & \multirow[t]{3}{*}{0.634} & $2.52 \pm 0.91$ & \multirow[t]{3}{*}{0.445} \\
\hline GA & $2.55 \pm 0.96$ & & $2.46 \pm 1.00$ & & $2.64 \pm 0.91$ & \\
\hline AA & $2.31 \pm 0.76$ & & $2.26 \pm 0.66$ & & $2.35 \pm 0.86$ & \\
\hline
\end{tabular}

of analyzed polymorphisms were in Hardy-Weinberg equilibrium. There was no statistically significant difference between male and female adolescents in frequencies of PRDM16 $(p=0.476)$ and CtBP2 ( $p=0.816)$ genotypes. Mean values of analyzed parameters depending on the PRDM16 and CtBP2 genotypes are shown in Table III and Table IV respectively.

Statistical analysis has shown that there is a statistically significant difference in mean values of TC $(p=0.037)$ and borderline significance in mean values of LDL-C ( $p=0.054)$ depending on PRDM16 genotype in the group of girls. Girls carrying TT genotype had a significantly higher TC level and a tendency towards a higher LDL-C level. However, when we performed multiple linear regression analysis using fasting glucose level and $\mathrm{BMI}$ as covariates we could not confirm these results. Children were further grouped according to their PRDM 16 and CtBP2 genotypes in groups with $\mathrm{TT}+\mathrm{GG}$ genotypes, CT+GG genotypes, TT+GA/AA genotypes and $\mathrm{CT}+\mathrm{GA} / \mathrm{AA}$ genotypes, respectively. Combination of $\mathrm{CC}+\mathrm{GA}$ genotypes was observed in just one patient while other combinations of genotypes were not recorded in our study group. Statistical analysis showed that carriers of $C T+G G$ genotype have significantly lower TC $(p=0.005)$ and LDL-C $(p=0.032)$ levels compared to all other groups (Table $\mathrm{V})$. These results were confirmed by multiple linear regression analysis for both TC $(\beta=-0.198, p=0.001)$ and LDL-C $(\beta=-0.159$, $p=0.008)$ using gender, $\mathrm{BMI}$ and fasting glucose level as covariates.

\section{Discussion}

It has been previously reported that BAT has an important role in weight determination $[2,19]$. 
Table V. Mean values of analyzed parameters by combined PRDM16 and CtBP2 genotypes (mean \pm SD)

\begin{tabular}{|lccccccc|}
\hline Genotypes & $n(\%)$ & BMI & FPG & Tg & TC & HDL-C & LDL-C \\
\hline TT+GG & $101(34.35)$ & $21.86 \pm 3.94$ & $4.70 \pm 0.59$ & $0.94 \pm 0.40$ & $4.47 \pm 0.92$ & $1.43 \pm 0.37$ & $2.58 \pm 0.83$ \\
\hline CT+GG & $27(9.18)$ & $22.01 \pm 3.82$ & $4.67 \pm 0.48$ & $0.86 \pm 0.34$ & $3.81 \pm 0.57$ & $1.40 \pm 0.36$ & $2.04 \pm 0.58$ \\
\hline TT+GA/AA & $141(47.96)$ & $22.12 \pm 4.62$ & $4.75 \pm 0.61$ & $1.06 \pm 0.69$ & $4.35 \pm 0.85$ & $1.40 \pm 0.45$ & $2.46 \pm 0.92$ \\
\hline CT+GA/AA & $25(8.51)$ & $23.01 \pm 5.00$ & $4.71 \pm 0.50$ & $0.96 \pm 0.41$ & $4.53 \pm 0.88$ & $1.45 \pm 0.37$ & $2.62 \pm 0.88$ \\
\hline$P$-value & & 0.805 & 0.897 & 0.458 & $0.005^{*}$ & 0.897 & $0.032^{*}$ \\
\hline
\end{tabular}

${ }^{*} P$-value $<0.05$

In the study of Matsushita et al. [7] healthy, adult subjects with and without detectable BAT were compared. Subjects with detectable BAT were younger and showed lower adiposity-related parameters such as BMI, body fat mass, and abdominal fat area. It has also been observed that blood glucose, total cholesterol and LDL cholesterol were significantly lower in the BAT-positive group. Our aim was to investigate whether polymorphisms of genes important for expression of BAT and repression of white adipose tissue (WAT) formation may influence BMI, glucose level and lipid profile of adolescents. PRDM16 is a co-regulatory protein crucial for BAT development. Its main role is to induce BAT formation through co-activation of PGC $1 \alpha$, PPAR $\alpha$, PPAR $\gamma, C / E B P$ and thyroid receptor genes [10] and repress the expression of white cells specific genes by interacting with CtBP1 and CtBP2 co-repressors [20]. The results of Urano et al. showed that the rs12409277 single nucleotide polymorphism (SNP) influences transcriptional activity of the PRDM16 gene. The presence of the $\mathrm{C}$ allele corresponds with higher expression activity [12] and therefore higher volume and activity of BAT/beige WAT. In our study we did not find a statistically significant association between this polymorphism and BMI, fasting glucose and lipid profile of all adolescents. In the group of girls an association between PRDM 16 rs 12409277 polymorphism and TC level was observed. During puberty there is an increase in production of growth hormone, growth factors, gonadotropins and sex steroid hormones that might influence BAT activity [4]. Therefore, the possible explanation for the gender-specific result we obtained might be the difference in growth and sexual maturity between boys and girls in our study group. However, our result was not confirmed by multiple linear regression analysis.

The same polymorphism was analyzed [12] in the group of postmenopausal women. Results of this study have shown that presence of CC or CT genotypes is significantly associated with higher lean body mass. In the study of AlAmrani et al. wild type genotype of PRDM16 rs2651899 polymorphism was associated with higher blood cho- lesterol, HDL-C and LDL-C and with lower triglyceride level [21]. Also, it has been suggested that presence of mutated alleles (GA and AA genotype) increases the risk of obesity. Yue et al. investigated the rs2236518 polymorphism located in the 3'UTR region of the PRDM16 gene and detected an association with $\mathrm{BMI}$ in both young males (20-40 years) and older males (50-80 years) [22]. Park et al. tested the association of PRDM16 rs17390167 and susceptibility to metabolic syndrome (MetS) and found a significant trend but the results did not reach the statistical threshold in cohorts from the Framingham Heart Study [23]. Zhang et al. in their study observed a negative association between rs2236518 and susceptibility to MetS in Uygur Chinese subjects [24].

Our analysis of CtBP2 rs1561589 polymorphism also did not reveal a statistically significant association with any of the analyzed parameters. The same polymorphism was investigated in the genome-wide association study (GWAS) of Hinney et al. [14]. This study revealed the association of rs1561589 as well as two other intronic polymorphisms (rs126681170 and rs126674064) with susceptibility to anorexia nervosa and increased BMI, predominantly in females. They also analyzed these SNPs in the Early Growth Genetics Consortium data set that includes only children and adolescents and no significant findings were observed, which is in accordance with our results [25].

PRDM16 and CtBP2 form complexes that bind directly to the promoters of white fat tissue specific genes such as resistin and angiotensinogen and repress their expression [11]. Based on the knowledge of interaction between PRDM16 and CtBP2 proteins we investigated the combined effect of two analyzed polymorphisms. Our results have shown that carriers of CT genotype for the PRDM16 gene rs 12409277 and GG genotype of CtBP2 gene rs1561589 polymorphism have significantly lower levels of TC and LDL-C compared to all the other combinations of genotypes. Presence of the minor $C$ allele increases expression of the PRDM16 gene. The effect of intronic polymorphism in the CtBP2 gene has not yet been confirmed. However, based on the current knowledge 
it is possible that the presence of the minor allele reduces the expression or activity of CtBP2 either directly or by being in linkage disequilibrium with another, still unknown functional polymorphism. Therefore, it is possible that carriers of $\mathrm{CT}+\mathrm{GG}$ genotypes have higher expression of PRDM16 and CtBP2 and consequently less WAT and more BAT. To our knowledge this is the first study that has investigated the combined effect of PRDM16 and CtBP2 gene polymorphisms.

One limitation of our research is the lack of data about non-genetic factors that could influence the BMI, glucose level and lipid profile of adolescents. It is known that lifestyle, nutritional behavior and medications can modify lipid status [25]. The studies of Bergier et al. and Junger et al. have shown that boys are more active than girls, while girls, who in a very small percentage fulfill the physical activity recommendations, have better nutritional behavior $[27,28]$. Also, an association between the PRDM16 and CtBP2 genotypes and TC was observed only in the population of healthy adolescents, and the long-term health impact of this association is not clear. Some studies investigated the tracking of blood lipid changes from adolescence to adulthood and their results supported the importance of measuring lipids during adolescence for identifying individuals with high risk for cardiovascular disease [29, 30]. Still, there is not enough evidence about the importance of early measurement of lipids [31].

In order to draw definite conclusions it would be of great interest to further analyze the association of combined PRDM16 and CtBP2 genotypes with lipid profile of adolescents and adults on a larger population, taking into consideration non-genetic factors as well.

\section{Acknowledgements}

This work was supported by the Serbian Ministry of Education, Science and Technological development (Grant 175091).

\section{Conflict of interest}

The authors declare no conflict of interest.

\section{References}

1. Gilsanz V, Hu HH, Kajimura S. Relevance of brown adipose tissue in infancy and adolescence. Pediatr Res 2013; 73: 3-9.

2. Sharp LZ, Shinoda K, Ohno H, et al. Human BAT possesses molecular signatures that resemble beige/brite cells. PLoS One 2012; 7: e49452.

3. Kajimura S, Seale P, Spiegelman BM. Transcriptional control of brown fat development. Cell Metab 2010; 11: 257-62.

4. Gilsanz V, Smith ML, Goodarzian F, Kim M, Wren TA, $\mathrm{Hu} \mathrm{HH}$. Changes in brown adipose tissue in boys and girls during childhood and puberty. J Pediatr 2012; 160: 604-9.
5. Rodriguez-Cuenca S, Monjo M, Frontera M, Gianotti M, Proenza AM, Roca P. Sex steroid receptor expression profile in brown adipose tissue. Effects of hormonal status. Cell Physiol Biochem 2007; 20: 877-86.

6. Hioki C, Yoshida T, Kogure A, et al. Effects of growth hormone $(\mathrm{GH})$ on mRNA levels of uncoupling proteins 1,2 , and 3 in brown and white adipose tissues and skeletal muscle in obese mice. Horm Metab Res 2004; 36: 607-13.

7. Matsushita M, Yoneshiro T, Aita S, Kameya T, Sugie H, Saito M. Impact of brown adipose tissue on body fatness and glucose metabolism in healthy humans. Int J Obes 2014; 38: 812-7.

8. Ozguven S, Ones T, Yilmaz Y, Turoglu HT, Imeryuz N. The role of active brown adipose tissue in human metabolism. Eur I Nucl Med Mol Imaging 2016; 43: 355-61.

9. Chondronikola M, Volpi E, Borsheim E, et al. Brown adipose tissue activation is linked to distinct systemic effects on lipid metabolism in humans. Cell Metab 2016; 23: $1200-6$.

10. Seale P. Transcriptional regulatory circuits controlling brown fat development and activation. Diabetes 2015; 64: 2369-75.

11. Kajimura S, Seale P, Tomaru T, et al. Regulation of the brown and white fat gene programs through a PRDM16/ CtBP transcriptional complex. Genes Dev 2008; 22: 1397-409.

12. Urano T, Shiraki M, Sasaki N, Ouchi Y, Inoue S. Largescale analysis reveals a functional single-nucleotide polymorphism in the 5'-flanking region of PRDM16 gene associated with lean body mass. Aging Cell 2014; 13: 739-43.

13. Chinnadurai G. CtBP family proteins: more than transcriptional corepressors. Bioessays 2003; 25: 9-12.

14. Hinney A, Kesselmeier M, Jall S, et al. Evidence for three genetic loci involved in both anorexia nervosa risk and variation of body mass index. Mol Psychiatry 2017; 22: 321-2.

15. Nedeljkovic S, Vukotic M, Simeunovic S, et al. Antropometrijski parametri kod školske dece stare 10 i 15 godina u JUSAD. In: Nedeljkovic S, Simeunovic S, Vukotic M, editors. Jugoslovenska studija prekursora ateroskleroze kod školske dece. Belgrade: Faculty of Medicine, Belgrade University; 2006, pp. 429-38.

16. Miller SA, Dykes DD, Polesky HF. A simple salting out procedure for extracting DNA from human nucleated cells. Nucleic Acids Res 1988; 16: 1215.

17. Majkic-Singh N, Ilic M, Jankovic O, Ignjatovic S, Obradovic I. Trendovi u nalazima lipidnih frakcija u JUSAD studiji. In: Nedeljkovic S, Simeunovic S, Vukotic M, editors. Jugoslovenska studija prekursora ateroskleroze kod skolske dece. Belgrade: Faculty of Medicine, Belgrade University; 2006, pp. 323-34.

18. Friedewald WT, Levy RI, Fredrickson DS. Estimation of the concentration of low-density lipoprotein cholesterol in plasma, without use of the preparative ultracentrifuge. Clin Chem 1972; 18: 499-502.

19. Garcia CA, Van Nostrand D, Atkins F, et al. Reduction of brown fat 2-deoxy-2-[F-18]fluoro-D-glucose uptake by controlling environmental temperature prior to positron emission tomography scan. Mol Imaging Biol 2006; 8: 24-9.

20. Chi J, Cohen P. The multifaceted roles of PRDM16: adipose biology and beyond. Trends Endocrinol Metab 2016; 27: 11-23.

21. AlAmrani A, AbdelKarim M, AlZoghaibi M. PRDM16 gene polymorphism is associated with obesity and blood lipids profiles in Saudi population. J Clin Med 2018; 7: 141. 
22. Yue $\mathrm{H}, \mathrm{He} J \mathrm{~W}, \mathrm{Ke} \mathrm{YH}$, et al. Association of single nucleotide polymorphism Rs2236518 in PRDM16 gene with BMI in Chinese males. Acta Pharmacol Sin 2013; 34: 710-6.

23. Park YM, Province MA, Gao X, et al. Longitudinal trends in the association of metabolic syndrome with $550 \mathrm{k}$ single-nucleotide polymorphisms in the Framingham Heart Study. BMC Proc 2009; 3 Suppl 7: S116.

24. Zhang JH, Li NF, Yan ZT, et al. Association of genetic variations of PRDM16 with metabolic syndrome in a general Xinjiang Uygur population. Endocrine 2012; 41: 539-41.

25. Bradfield JP, Taal HR, Timpson NJ, et al. A genome-wide association meta-analysis identifies new childhood obesity loci. Nat Genet 2012; 44: 526-31.

26. Soran H, Adam S, Mohammad J, et al. Hypercholesterolaemia - practical information for non-specialists. Arch Med Sci 2018; 14: 1-21.

27. Bergier J, Niźnikowska E, Bergier B, Acs P, Salonna F, Junger J. Differences in physical activity, nutritional behaviours, and body silhouette concern among boys and girls from selected European countries. Hum Mov 2018; 18: 19-28.

28. Junger J, Kačúr P, Tlučáková L, Čech P, Bebčáková V. Physical activity of female students in secondary schools in the context of physical activity recommendations fulfilment. Hum Mov 2018; 18: 67-73.

29. Lee JH, Kim HC, Kang DR, Suh I. The 23-year tracking of blood lipids from adolescence to adulthood in Korea: the Kangwha study. Lipids Health Dis 2017; 16: 221.

30. Adams C, Burke V, Beilin LJ. Cholesterol tracking from childhood to adult mid-life in children from the Busselton study. Acta Paediatr 2005; 94: 275-80.

31. US Preventive Services Task Force; Bibbins-Domingo K, Grossman DC, Curry SJ, et al. Screening for lipid disorders in children and adolescents: US preventive services task force recommendation statement. JAMA 2016; 316 : 625-33. 